\title{
LAIN TUULIA AVOIMEN TIETEEN PURJEISSA
}

Vuonna 20 I 5 haastattelin yliopistokirjastojen asiantuntijoita avoimesta julkaisemisesta opinnäytetyötäni varten. He olivat yksimielisiä siitä, että muutos kohti avointa tiedettä tapahtuu sitovien linjausten ja akateemista maailmaa ohjailevien tahojen, kuten tutkimusrahoittajien ja ministeriön, tuella.

Sittemmin on nähty, miten on käynyt. Suurten tutkimusrahoittajien Plan $S$-linjaus on kiihdyttänyt vauhtia kohti avointa julkaisemista ja hinnoittelun läpinäkyvyyttä. Opetus- ja kulttuuriministeriön värkkäämä open access -kerroin yliopistojen rahoitusmallissa taas on osaltaan lisännyt tieteellisten julkaisujen avointa saatavuutta suomalaisissa korkeakouluissa.

Euroopan unioni on jo pitempään tukenut siirtymää kohti avointa tiedettä, ensin tutkimusjulkaisuissa ja nykyään yhä enemmän tutkimusdatan ja -aineistojen kohdalla.

Tämän vuoden heinäkuussa astui voimaan tutkimusaineistolaki eli laki julkisin varoin tuotettujen tutkimusaineistojen uudelleenkäytöstä. Uusi laki liittyy Eu:n avoimen datan direktiiviin, jonka tavoitteena on ulottaa tietoaineistojen uudelleenkäyttö myös tutkimusaineistoihin.

Toinen ajankohtainen laki liittyy DSM-direktiiviin (Digital Single Market), joka koskee tekijänoikeutta ja lähioikeuksia EU:n digitaalisilla sisämarkkinoilla. Direktiivi olisi pitänyt tuoda kansalliseen lainsäädäntöön kesällä, hallituksen esitys tullee lausuntokierrokselle ja eduskunnan käsittelyyn tämän syksyn aikana.
Tuleva laki sisältää tiedeyhteisön ja kirjastojen kannalta ainakin kaksi seurattavaa asiaa, tiedonlouhinnan ja rinnakkaistallennusoikeuden. Tiedonlouhinnan osalta Suomen tieteellinen kirjastoseura painotti kannanotossaan jo keväällä 2020 mahdollisimman vapaata tutkimuskäyttöä ja selkeitä pelisääntöjä tiedonlouhinnan käytäntöön.

Rinnakkaistallennusoikeutta, joka on jo voimassa kuudessa EU-maassa, ajetaan läpi direktiivin kansallisen käsittelyn yhteydessä. Käytännössä se antaisi tutkijalle mahdollisuuden rinnakkaistallentaa oma julkaisunsa kustantajan linjauksista riippumatta. Julkaisuarkistoista vastaavien kirjastojen näkökulmasta se selkiyttäisi nykytilannetta, jossa rinnakkaistallennusehdot selvitetään julkaisukohtaisesti.

Vielä on vaikea sanoa, miten lait edistävät tieteen avoimuutta. Tutkimusaineistolain väljät muotoilut jättävät paljon sen varaan, millaiseksi käytännöt muodostuvat, ja rinnakkaistallennusoikeuden kohdalla syksy näyttää, päästäänkö siinä alkuun.

Yksi asia on silti varma, ja tämäkin kävi selväksi jo opinnäytetyössä: tieteelliset kirjastot ovat jatkossakin avainasemassa avoimen tieteen edistämisessä käytännön tasolla, palveluiden tarjoajana ja koordinoijana sekä kouluttajana. Onkin syytä toivoa, että esimerkiksi yt-neuvotteluja käyvässä Tampereen yliopistossa kirjaston rooli tutkimuksessa ja opetuksessa ymmärretään. Tieteen avoimuus vaatii linjausten rinnalle riittävät tukirakenteet. 